\title{
"RED TIDE" IN WASCANA LAKE
}

by M. V. S. Raju, Biology Dept., University of Saskatchewan, Regina

In many parts of the world, particularly in the oceans, certain algae (commonly known as "water scum") bloom periodically in great abundance giving such an extremely intense red coloration that it has aptly been termed the "red tide." Such a phenomenon is occasionally seen in oceans, estuaries and fresh-water lakes. A similar red tide was observed early in the summer of 1969 in several parts of Wascana Lake and remained very prominent particularly in the months of July and August. It was earlier observed by the author in the summer of 1966 when the red color was not very intense and was confined to in-

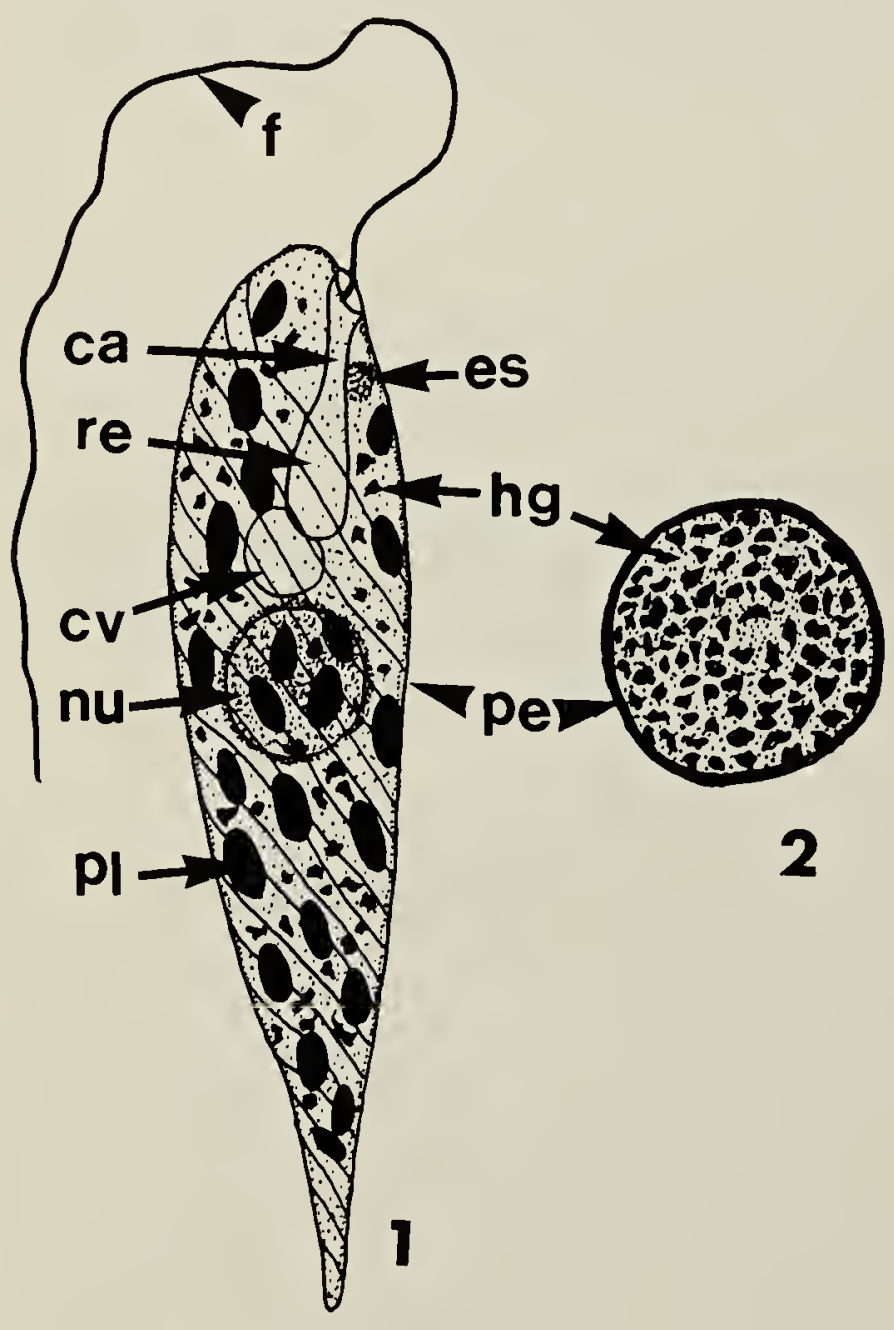

Fig.1. Diagrammatic sketch of an actively moving Euglena cell to show the cellular details.

Fig. 2. A dormant cell of Euglena. (Explanation of labelling: ca, canal; cv, contractile vacuole; es, eye-spot; f, flagellum; hg, hemat ochrome granule; nu, nucleus; pe, pellicle; pl, plastid; re, reservoir.) significantly small areas. Since then it has become increasingly abundant in the lake. Prompted by curiosity, a periodic collection of this red scum was made from various points in Wascana Lake, particularly in the Wascana Waterfowl Park area. Although this part of the lake was abundantly infested by a wide variety of green and blue-green algae (Fig. 6 ), attention was directed toward the unusually prominent red scum, color of which is not visible here (Fig. 5). A detailed examination of the red scum revealed that the organism which was causing the red tide was a species of Euglena, a member of the flagellate green algae.

Euglena occurs in nature as a unicellular alga growing abundantly in foul-smelling water, around old manure heaps, old farm yards, etc. In fact, a decent culture of this alga can be maintained, according to reports, very successfully for a long time on a culture medium containing rabbit droppings. Some species are known to occur in great abundance in sewage oxidation ponds. In these situations the cells can multiply with enormous rapidity because they metabolize successfully even under anaerobic conditions.

The single cell or the protoplast (Fig. 1) of Euglena does not possess a true cell wall that is commonly seen in most other plants. Instead, the protoplast has a highly modified peri-

Fig. 3. Actively moving cells after they were revived from dormant condition in the laboratory. Note different shapes of cells. $x 200$.

Fig. 4. Encysted dormant cells with abundant hematochrome granules. $\mathrm{x} 200$.

Fig. 5. Picture to show algae at the edge of the lake (eg, euglena red tide; ga, different genera of green algae).

Fig. 6. Picture showing algal bloom in the Wascana Waterfowl Park. 


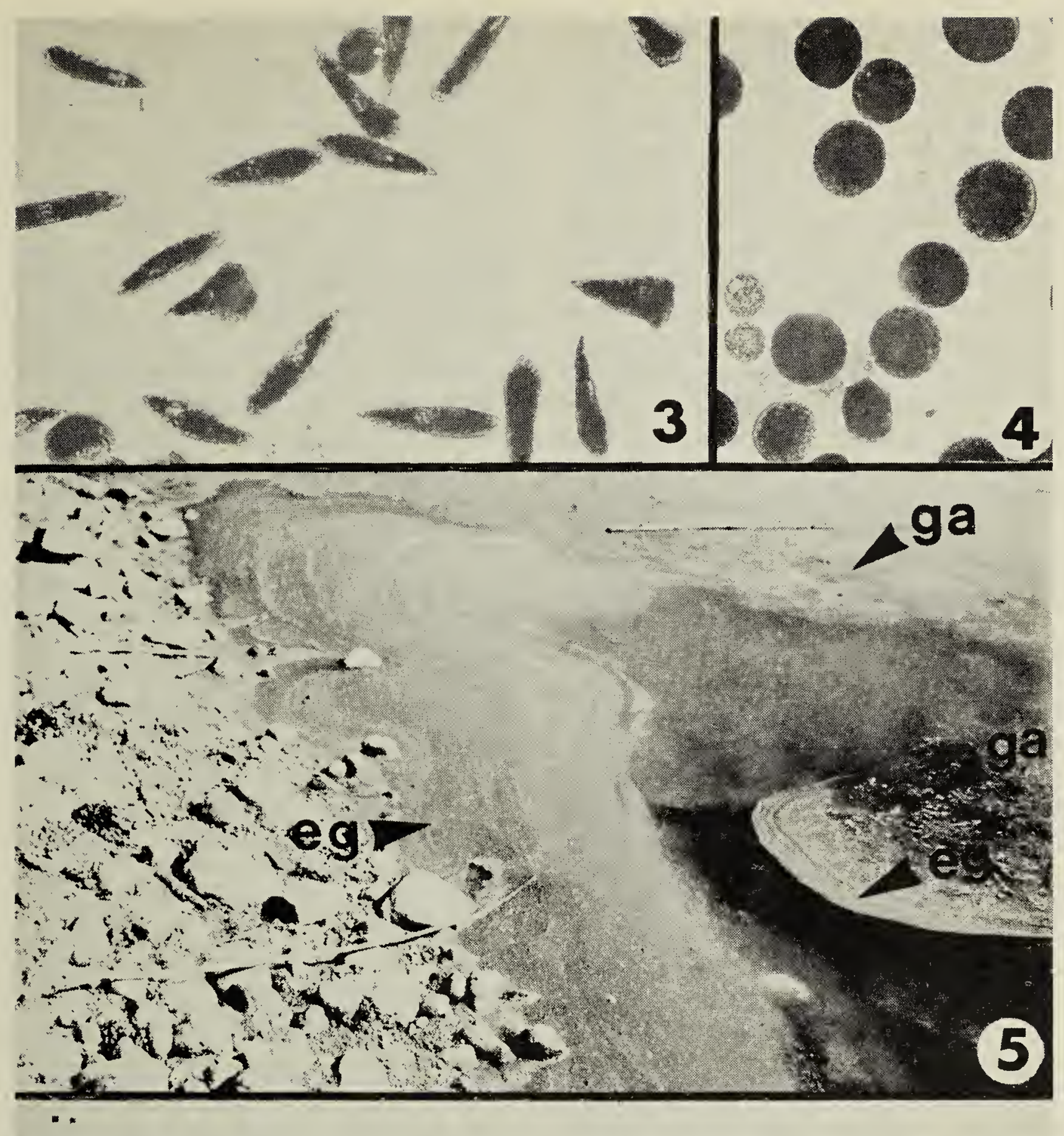

Aris

cen-

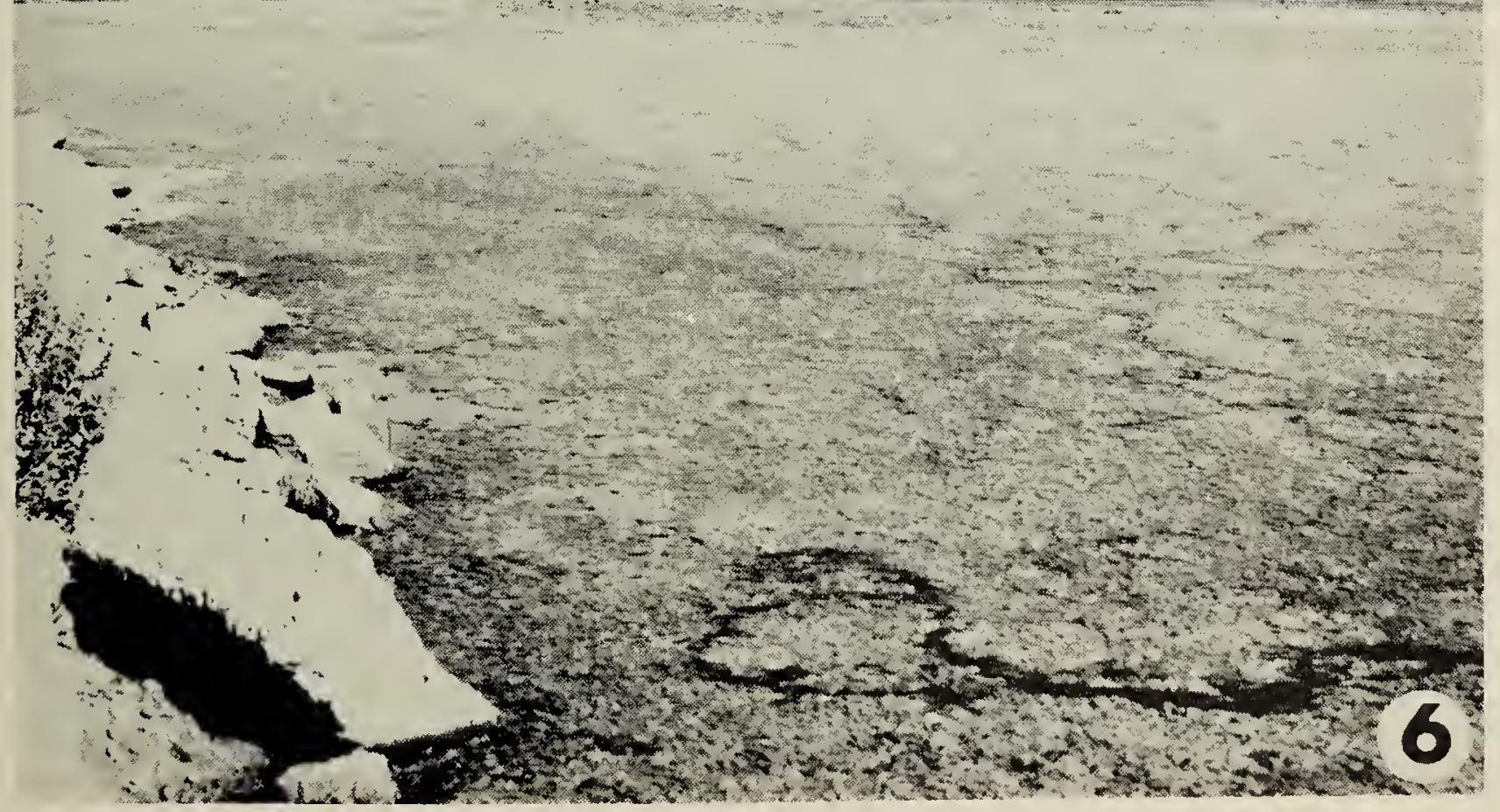

March, 1970 
pheral region called the "periplast" or "pellicle." The pellicle in Euglena is flexible in the sense that it shows rhythmic expansion and contraction depending on whether the alga is in motion or not (Fig. 3). The nucleus and the plastids can be recognized easily under the microscope (Fig. 1). The green plastids are extremely useful in photosynthesis and through this process the cell can synthesize carbohydrates which are normally stored within the cell. At the anterior end of the cell there is an opening which leads into an invagination called the "gullet" which is composed of an upper "canal" and lower "reservoir" (Fig. 1). The opening and the gullet are useful in the direct ingestion of minute food particles and other micro-organisms for the nutrition of the cell. Adjacent to the reservoir and often closely associated with it are afew contractile vacuoles which help in the translocation of ingested food particles into the body of the cell (Fig. 1).

Arising from the floor and passing through the gullet to the exterior there is an elongated whip-like flagellum (Fig. 1) whose constant lashing, in addition to rhythmic expansion and contraction, helps in the motility of the cell (Fig. 3). The movement is further known to be aided by a redpigmented body or eye-spot situated adjacent to the gullet toward the anterior end (Fig. 1).

The cells of Euglena collected from the Wascana Waterfowl Park contained small granules distributed between plastids. Such granules containing a pigment, hematochrome, become extremely conspicuous under certain conditions; several millions of such cells aggregated in dense masses along the edges of the lake and along the periphery of other green algae gave a brick-red color, which phenomenon is the "red tide" (Fig. 5). In an actively moving cell, the plastids remain peripherally placed, almost overshadowing the hematochrome granules, and the cells consequently show green color (Fig. 1). On a hot day, however, when the intensity of sunlight is high, the cells of Euglena have a tendency to become sluggish and almost stationary (Fig. 3). Such cells become rounded and a thick pellicle appears around each (Fig. 2, 4). At the same time, the cell loses its flagellum or retracts it until the advent of favorable conditions. In most of such dormant cells the green plastids get aggregated in the middle and they are surrounded by the hematochrome granules (Fig. 2, 4). Consequently, the green color of the plastids is masked and the cells look brilliant brick-red or blood-red, particularly in the months of July and August in the prairies when the sun is very bright and the temperature remains high. If the cells are placed in the laboratory at room temperature and under low light intensity, the encysted cells gradually start changing their shape showing a pulsating or wriggling movement (Fig. 3) until the cells produce their own flagella which help in the characteristic directional movement of cells.

The cells of Euglena are known to multiply vegetatively by longitudinal splitting. There are also some reports which indicate that the cells can divide in the encysted condition by producing more cells. These cells are liberated to the exterior after the rupture of the parent cell wall.

In the light of published information and of the present observations, the occurrence of the "red tide" in Wascana Lake can be interpreted as an instance of extreme algal bloom. One can also draw from this two important conclusions. Firstly, the area in which the alga, Euglena, is growing luxuriantly must be unusually and supra-optimally rich in nutrients. This phenomenon may popularly be referred to as "pollution." Secondly, it is possible that this bloom is an indication of the competive ability of the alga. This can be achieved by developing certain internal mechanisms, many of which are not clear at present, that aid the alga in the maximum exploitation of available nutrients. The alga can compete by producing certain toxins that may be detrimental to other algae, and to other flora and fauna. In fact, there 
are several published reports, although not exactly on Euglena, which show that blue-green algae, such as Microcystis, Anabaena, Aphanizomenon, which are also abundant in Wascana Lake, are known to produce substances that are toxic to some of the associated flora and fauna. Although there is not much convincing evidence to show that Euglena produces substances of the toxic type, it is possible that it could. Active research in this direction is phenomenally slow.

Euglena and some blue-green and green algae are known to be good indicators of pollution. They can thrive well in ponds and lakes containing high concentrations of organic and inorganic substances which could be inhibitory to the normal growth and development of other organisms. They are known to grow successfully on sewage where there is high depletion of oxygen, and also in other polluted areas caused by mine wastes. In view of all the evidence at hand, one should undoubtedly be concerned with the "red tide" of Euglena in Wascana Lake. There are also many other green and blue-green algae that may have contributed directly or indirectly to the supposedly polluted areas of Wascana Lake.

Although there is circumstantial evidence showing that Wascana Lake, at least in areas where Euglena redtide was noticed, is polluted, still we are not certain as to the type of pol- lution, whether it is formed as a result of natural causes within the lake itself and/or of man's intervention in some way. In nature we always recognize the death of larger consumers, such as birds, fish, etc., and attribute it to pollution. The death of consumers may be due to several factors: the algae by themselves may be toxic or they may release toxins into the environment and bring about mortality among both producers and consumers that live there. In view of our limited knowledge of the facts of pollution, serious efforts should be made to study intensively various aspects of the biology and biochemistry of the flora and fauna of Wascana Lake with particular reference to the producers such as algae and other micro-organisms. A detailed study of the environment in which such organisms live is also imperative. In regard to the red tide of Euglena, it is important to determine the internal and external factors that stimulate phenomenally the growth and development of the alga.

Considerable time, effort and money should be expended to carry out detailed biological investigations of Wascana Waterfowl Park and other adjacent areas. The results of such work could not only be exemplary for the prairies but could also help solve the problem of fresh-water lake pollution. Work of this sort may also give some clues that would be significant enough to effect proper measures of pollution control.

\section{NEW OR UNUSUAL PLANT RECORDS FOR SASKATCHEWAN, 1969}

\section{by John H. Hudson, 81 Morris Drive, Saskatoon}

This summer I was given material of a Silene which appears to be $S$. conoidea L. It was collected July 14 on the farm of Mrs. P. Bayoff, 3 miles S. of Verigin, when it had been growing as a weed in a barley field. As I did not see the plant alive, I shall not try to describe it; a description will be found in Boivin, Vol. 2, p. 94. He reports it from Lacombe, Alberta. A question may be asked about rare weeds of European origin like this; are they recent introductions (in which case they'll spread) or have they been with us since the early days of settlement, but aren't very aggressive?

I found Naias flexilis (Willd.) Rostk. \& Schmidt on August 10, 1969, in Pike Lake just west of the public 